\title{
Human Resource Training to Enhance Intellectual Capital in the Public Sector: A proposal of a Training Evaluation Model
}

\author{
Barbara Iannone ${ }^{1}$ \\ ${ }^{1}$ Department of Philosophical, Pedagogical and Economic-Quantitative Sciences - "G. d'Annunzio" University of \\ Chieti-Pescara, Pescara, Italy \\ Correspondence: Barbara Iannone, Department of Philosophical, Pedagogical and Economic-Quantitative Sciences - \\ "G. d'Annunzio" University of Chieti-Pescara, Viale Pindaro, 42, 65127- Pescara, Italy. Tel: 39-85-453-7906.
}

Received: August 5, 2019

doi:10.5430/ijba.v10n5p10
Accepted: September 3, $2019 \quad$ Online Published: September 5, 2019

URL: https://doi.org/10.5430/ijba.v10n5p10

\begin{abstract}
The evaluation of Human Resources (HR) training, particularly in Public Administration (PA), has been the focus of studies and in-depth analysis for several decades. This paper proposes an additional model of evaluating HR training in Public Administration. The improvement of performances in PA is indeed an HR issue. Therefore, it is necessary to plan and invest in HR training, as a key component of empowering the employees' knowledge, skills and abilities, with the intention of enhancing the intellectual capital of the organization, adding value to the PA. Another contributing point of this research is the assessment of training HR on intangible aspects, such as the reputation of the PA. Lastly, it is essential to build and to adopt an optimal process of evaluation of HR training to measure the return on investments in terms of tangible and intangible assets.
\end{abstract}

Keywords: training, Public Administration (PA), Human Resources (HR), evaluation, intellectual capital, stakeholders

\section{Introduction}

Over the last few decades, Public sector organizations worldwide have been under pressure to improve their performances and win public trust (Talbot, 2010, Miao et al., 2017). This pressure may result from the notable inefficiencies within the Public sector, such as in economic (Rothstein and Downer, 2012; Meier and O'Toole, 2011), social (Knott and Miller, 2006), organizational (Mayer et al., 1995; Meyer et al., 2014), and institutional aspects (Magone, 2011).

There are various reasons behind these failures, such as an obsessive and strict focus on rules and procedures that often fail to recognize and adapt to substantive changes. Despite the fact that NPM (New Public Management) doesn't expose real solutions for the different problems, there is a movement of new concepts surrounding Public Administration in the direction of "performance-oriented management" (Pollitt \& Bouckaert, 2000), and the rise of an "audit society" (Power, 2000), indicating that the world of public management has now become a world of measurement (Noordegraaf \& Abma, 2003).

The literature still acknowledges that Public Management continues to be anchored to an ancient tradition of bureaucratic, standardized, and repeated activities characterized by high rationality (Meek, 2010). There is still a need for significant progress towards a broad improvement of the quality of public services for stakeholders. There is a lack of attention focusing on individual behaviors in the public service environment that may affect individual and organizational performance. Behaviors shape, and are shaped by, personal qualities, interpersonal relationships, and are context-related (Tomo, 2018).

New models of governance, stretching from organizational structure to employee training, are therefore proposed to accommodate these new needs, for the quality of the people and employees. A strong foundation in a PA workplace, incorporating "knowledge" on Human Resources (Knowledge-based HR configuration), will directly enhance the intellectual capital, and affect organizational performance overall (Lin \& Tang, 2016). Furthermore, there will be an improvement in employees' commitment to the organization, and subsequent lowering of turnovers and absenteeism, which are notable problems in Public Organizations, and in Italy specifically. For these reasons, this paper will be focused on the training process and will propose a framework to evaluate this process through an audit system. 


\section{Theoretical Background}

The literature grounded in the public sector presents few studies examining behavioral issues (Hinna, et al., 2010). Scholars in this field have investigated aspects related to governance and expectations concerning boards' tasks in public administrations, using evidence related to strategic tasks (Jørgensen, 1999; Sullivan et al., 2006), control tasks (Hood et al., 2000; Sanderson, 2002; Smith and Beazley, 2000), or networking tasks (Klijn \& Skelcher, 2007; Lowndes \& Wilson, 2003). However, there have been a limited number of researchers focused on human aspects.

Human Resources (HR) is always the first element in every firm, company, or non-profit association, and a significant portion of investments are devoted to achieving competitive advantage, with employees enhancing their human capital as intangible assets (competencies, skills) which in turn affects the intellectual capital of the Organization.

It was during the 18th century that Adam Smith raised the importance of human capital in his study "The Wealth of Nations," in which he wrote an analogy comparing men and machines. He stated that economic resources are used for both the production of machines, and for the professional growth of people. It would be a mistake to neglect the economic growth achieved both internally and at a macro level, which is considered the nation's wealth factor.

Next, Marshall (1890) defined human capital in a holistic manner, including the energies, faculties and habits that directly contribute to the productive efficiency of men. Finally, the most meaningful contributions regarding the theories of human capital date back to the twentieth century and explain the impact at the macroeconomic level.

In 1986 the Organizational Support Theory (OST) explained the organizations' general contributions to the economy and its emotional connection, through the social exchange concept and the reward principle (Eisenberger et al., 1986). By this standard, the promises of organizations to their employees are the first priority, followed by the employees' commitments to organizations. The chiefs and the other members in an organization should create a relationship of mutual support according to the need for "self-fulfilled men." By general means, if an employee feels support and concern from their working managers, they will respond positively to managerial decisions. However, should the management level fail to create a supportive and sympathetic environment, with emotional connnections to their workers, the staff are more likely to respond negatively to managerial decisions. The Perceived Organizational Support (POS) is one concept supporting the Organizational Support Theory. It refers to employees' overall perception of organizations' concerns for their contributions and welfare. Later on, scholars discovered three factors that affect employees' POS (Rhoades and Einsemberger, 2002):

1. fairness of procedures,

2. support from leaders,

3. rewards and work conditions.

Focusing in on HR, there have been a lot of visable changes in this theme and various differences in terms of improvement (Juarez-Tarraga et al., 2019). The well-known resource-based view theory (Penrose, 1959; Wernerfelt, 1984; Barney, 1991) affirms positive associations between HR systems and organizational performance: furthermore, these researchers argued that organizational success is determined by internal resources. These resources are represented in either tangible or intangible assets (Collis, 1994), or capabilities such as knowledge and accumulated skills (Teece et al., 1997). HR represents an essential resource that makes sustained competitive advantage possible when the human capital possessed by employees is unique, difficult to replicate, difficult to substitute, and adds sufficient value to organizational production processes.

Some studies showed that effective HR practices affect intermediate outcomes, turnover, and productivity with a lower employee turnover and greater productivity, which in turn enhance corporate financial performance (Guthrie, 2001; Huselid 1995). They have also examined positive work attitudes (e.g., commitment, job satisfaction) and behaviors (e.g., organizational citizenship behavior) as possible intermediate outcomes to link HRM systems and firm performance (e.g., Gong et al., 2009; Rodwell \& Teo, 2008; Sun et al., 2007). Intellectual capital (e.g., Ordóñez de Pablos, 2004; Youndt \& Snell, 2004) and relation-based variables, such as top management team social networks (Collins \& Clark, 2003) and social capital manifested by interaction density, cooperation, and a shared code (Jiang \& Liu, 2015), can also serve as plausible mediators to explain why HR practices can influence organizational performance.

In the PA, organizational performance consists of elements such as knowledge on creating utility, problem solving management, enhancing satisfaction citizenship level, and having the ability to respond to the community's needs. These are just a few examples referring to an efficient and effective use of resources: tangibles and intangibles, 
aimed at obtaining maximum results from an increasingly limited quantity of resources available (Borgonovi, 2004). A trained and competent employee is the most valuable asset that an organization can have. For this reason, HR managers have increasingly shifted their mindset to consider training spending as more than cost, but as a real investment contributing to the implementation of the organization's strategies.

\section{The Added Value in Public Administration: The Public Value}

Since the start of the 1990's, scholars have been creating new theories about value creation in PA. One such theory, Porter's value chain, was introduced and is now considered well-known in the private sector. Porter analyzed firms and identified the sources of competitive advantage using the value chain model (Figure 1) which "disaggregates a firm into its strategically relevant activities in order to understand the behavior of costs and the existing and potential sources of differentiations" (Porter, 1985, p.33).

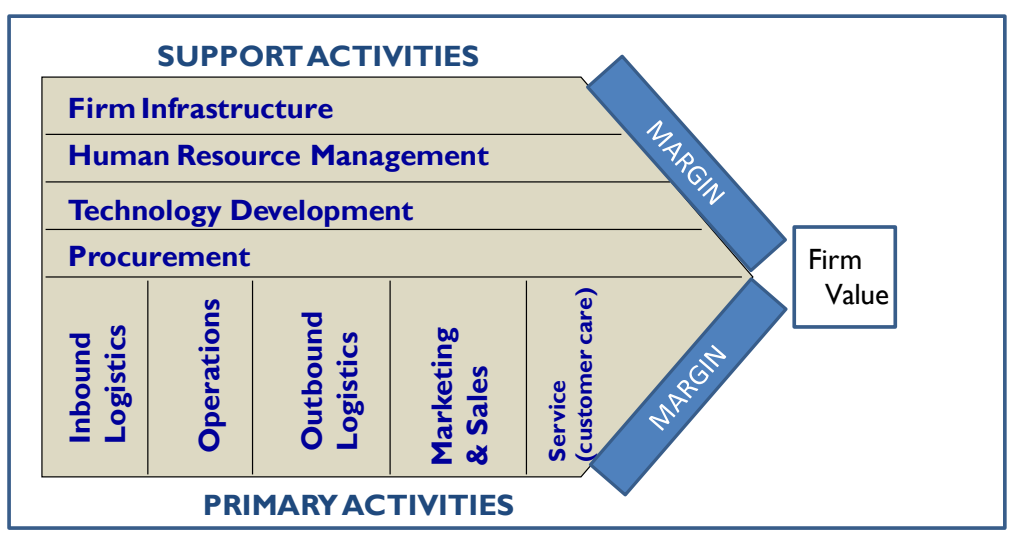

Figure 1. Porter's value chain - Porter (1985)

Primary activities are directly involved in the physical creation, sale, maintenance and support of a product or service. Support activities effectively support the previous primary: each support, or secondary, activity can play a role within the primary activity. For example, procurement supports operations with certain activities, but it also supports marketing and sales with other activities. HR supports every primary activity: allowing for the recruitment of a company, hiring, training, motivating, rewarding, and retaining its workers. People, better defined as employees, are a significant source of value, so businesses can create a clear advantage following the establishment of good HR practices (Porter, 1985).

The "translation" of this model in PA, as the value chain model applied to the PA, is shown in the Figure 2.

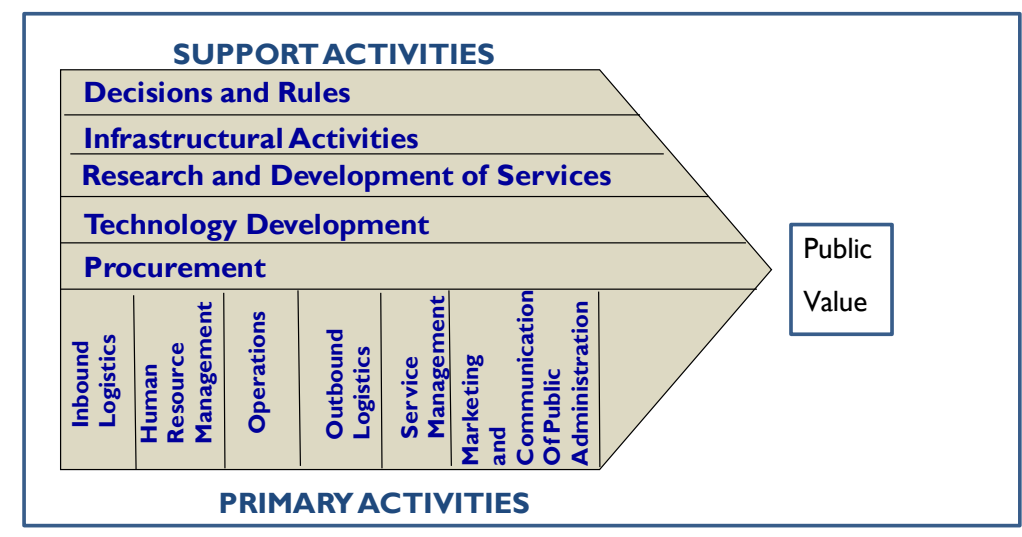

Figure 2. The value chain of quality services in PA - Meneguzzo (2005) 
The value chain for the private sector becomes the "service quality chain" for the public sector, thus focusing on the two concepts of service and quality. The service, as the final product of the PA, and the quality, as a key determinant for assessing the PA performance.

Therefore, the management of human resources becomes an integral part: it is among the primary activities, unlike the Porter model which includes among them those of support. Indeed, the HR in the PA is the characterizing element of the offer and management of the outgoing services. In some Organizations, such as healthcare, nursery schools, kindergartens, or universities, the activity aimed at managing HRs exceeds $65 \%$ of the entire costs of the structure. In this vein, HR becomes a privileged area in the process of creating public value.

As previously mentioned, the most valuable asset in an organization is a trained and competent employee. However, these skills don't remain forever: they deteriorate over time and can become obsolete as technology and expectations develop. For this reason, it is fundamental to implement training and develop activities which optimize the gap between employee's present and requisite knowledge and skills, thereby contributing to knowledge creation (De Winne \& Sels, 2010) and enhancing the value of the Human capital (Cabello-Medina, et al., 2011). Lastly, continuous employee development can be ensured through regular knowledge-based training and development, that works to expand the employees' knowledge and expertise on a consistent basis. Others scholars have noted a good relationship between knowledge-based HRM, Intellectual capital, and innovation performances. In this vein, HRs have a pivotal role: knowledge-based HRM practices impact the structural and relational capital in part through human capital, and human capital affects innovation performance by enhancing the structural and relational capital (Kianto et al., 2017).

The Figure 3 shows the overarching conceptual model assumed in this study, which permits to establish the pivotal role of HR, specifically focused in a PA.

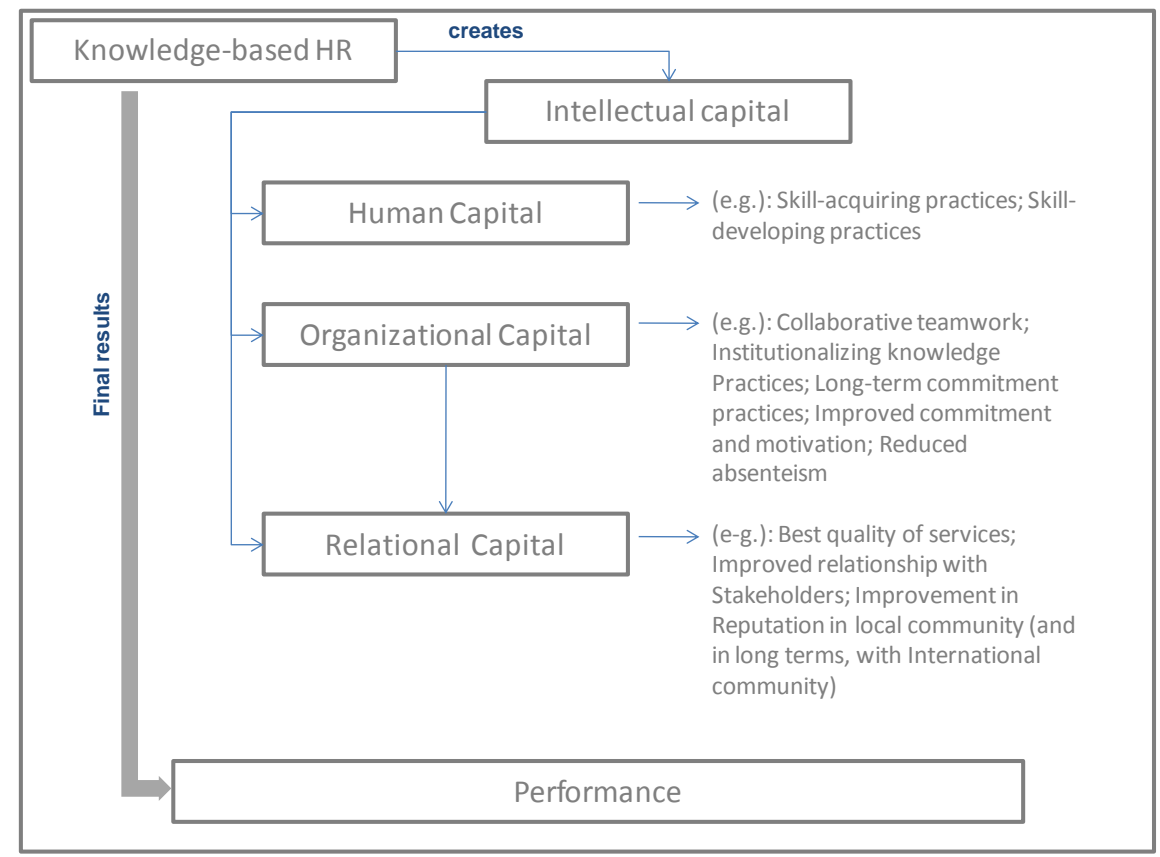

Figure 3. The role of HR in terms of intellectual capital and the final performance. source: own elaboration (adaptation framework by Kianto et al., 2017 p. 14; Lin and Tang, 2016, pp. 5 and 7)

\section{The Implementation of Training and Development Activities}

The foundation lies in designing a successful training program, which can serve as a fundamental incentive to encourage innovation in the workplace, and therefore establish creative organizational and managerial change aimed at creating new public value in the PA. Then, an efficient training program must be implemented in order to obtain the results in terms of Intellectual Capital and Innovation Performance. In this study it is suggested to follow a 
general guideline (Figure 4), as a basis to begin. In time, it is necessary to implement a more personalized design, according to the specific needs of the PA.

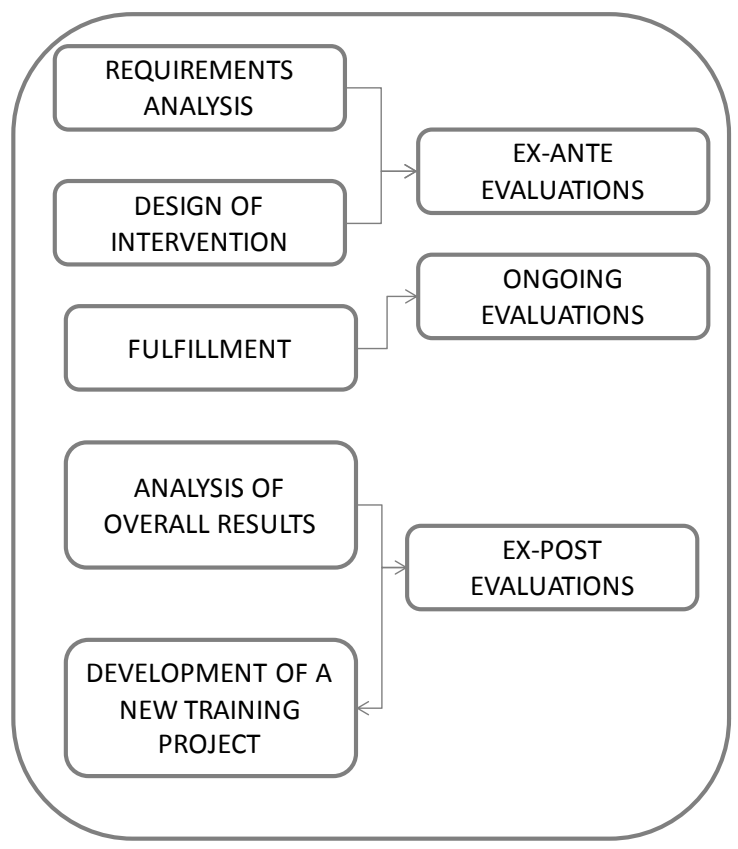

Figure 4. The guidelines about a training project

Immediately following the conclusion of the training activities, there is a pivotal evaluation phase which judges the efficiency and success of the activities. The evaluation of the investment in training activities has an inherent complexity, and includes two types of risks. The first type risk is recognizable in any type of Organizational investment, while the second type of risk surrounds the delicate nature of creating intellectual capital and realizing innovative performances.

With reference to a PA, the reporting of resources employed is drastically more important than in private companies, as they consist of public resources. The evaluation phase represents a central moment that impacts future decisions too, especially in consideration for future training actions. The main risk related to the evaluation moment would be misconceptions or mistakes formed off of a collection of data that was incorrectly or poorly gathered. Therefore, only after a correct evaluation will it be possible to decide which new training projects can be projected and implemented for the organization's future use.

\section{The Training Evaluation Model in a PA: A Proposed Idea}

As previously expressed, when the moment comes to carry out the evaluation for the training activity in the Public Sector, it is a wise to utilize evaluations regarding the three different phases:

1. ex-ante evaluations;

2. ongoing evaluations;

3. ex-post evaluations.

The first ex-ante evaluation is done with the initial required analysis of training needs, and leads to the choice of which training activity is considered the most adequate for obtaining the desired results. The second ongoing evaluation is adopted during the training activity and operates by monitoring whether the desired results are being achieved. In the case that good results are not obtained, it is possible to instantly correct the activities in order to avoid further waste of resources (Figure 5). 


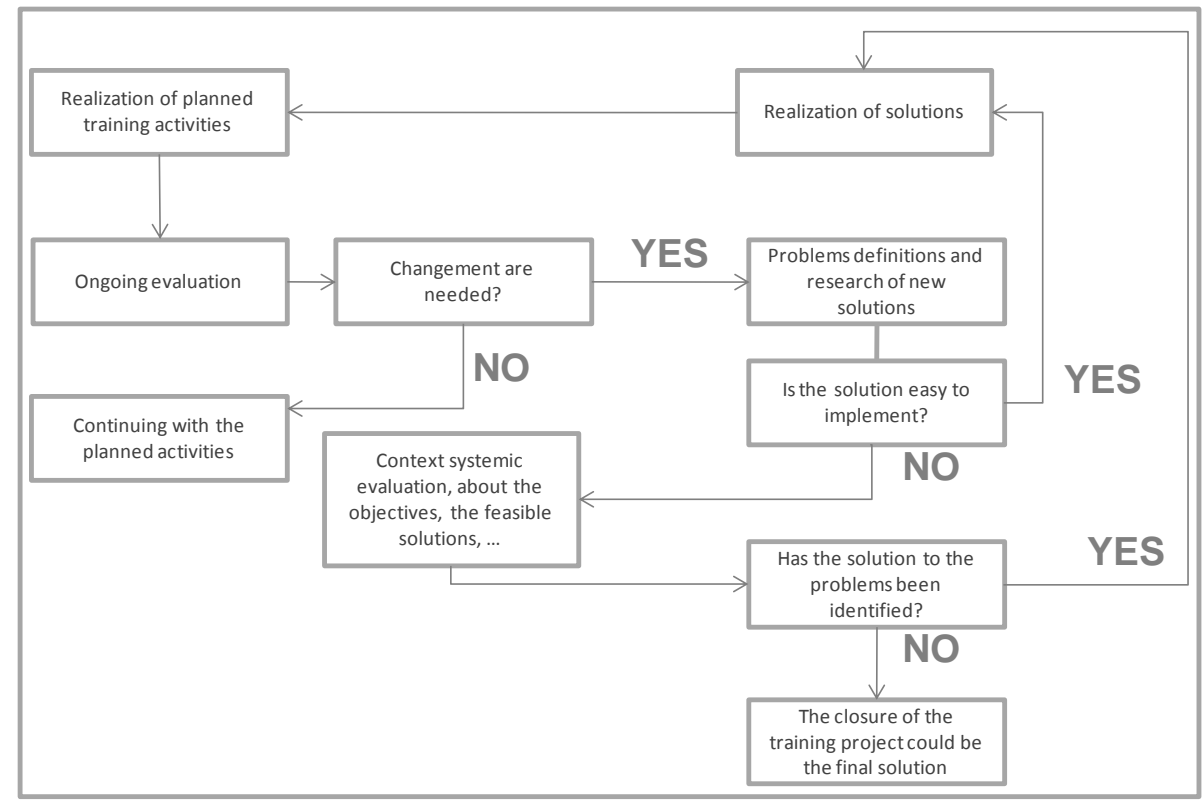

Figure 5. The ongoing evaluation

Finally, the ex-post evaluation is aimed at obtaining the information about the ended training activities. During this phase it is possible to determine a final judgment about the distance (or not) to initial objectives and final results.

In the literature, the most popular approach to the evaluation of training in organizations is the Kirkpatrick's framework (Kirkpatrick, 1959a, 1959b, 1960a,1960b, 1976, 1994; Kirkpatrick \& Kirkpatrick, 2005) of four levels of criteria. The four levels created by this model are: reactions; learning; job behavior; and company's results. On a deeper level, this model examines the content, therefore the changes recorded at work as a consequence of the effects of the course. The company's financial performances are quantified as the final moment generated by the training intervention. Then, further studies are focused on improving the evaluation phase concerning the training process. Among others, a significant result of this research was the benefit-cost ratio (BCR), well-known as the ROI of training (Kearsley - Compton, 1981; Kearsley, 1982, Philips, 1991, 1996, 1997; Phillips PP - Phillips JJ, 2001).

The cost-benefit analysis allows for a more detailed examination of costs and revenues with reference to a training project. It is a kind of analysis that is becoming increasingly important as a preventive assessment of the costs/opportunities and in regards to risk management as well. In this context, the risk associated with a training program would be failure of the program, or negative situations that diverge from the initial projections. In order to create an ideal framework to evaluate training activities in a PA, the model of utilization-focused evaluation is used (Patton, 1998). This model, unlike other evaluation systems, focuses on the results considered significant by the main users of the program: therefore, a small number of program's users are selected to work with the evaluator. Uniquely, it will consider the limitations of Kirkpatrick's training evaluation model (Bates, 2004) and attempt to go beyond these.

The evaluation activities focus on the following points:

a) functionality of the training program;

b) identification and measurement of training program performances;

c) identification of any proposals to improve the obtained performance.

In this vein, it is necessary to conduct an audit activity with the utilization-focused evaluation approach. Furthermore, according to a systematic approach to evaluation planning, a generally successful evaluation model must be able to answer the following ten questions:

I. What is the program to be evaluated?

II. Why is the program being evaluated?

III. How are people to prepare for the evaluation? 
IV. What are the main issues/questions with which the evaluation is to deal?

V. Who will do what?

VI. What are the resources for the evaluation?

VII. What data needs to be collected?

VIII. How will the data be analyzed?

IX. What will be the reporting procedure?

$X$. How will the report be implemented?

Then, it must build an evaluation process that includes the following phases:

1. identifying both who are the stakeholders to be involved and what are the objects of the evaluation (about the training program);

2. determining the criteria for quality assessments (KPIs, reference standards);

3. collection, selection and organization of data (methodologies to be adopted);

4. comparison between the performances obtained and the planned objectives;

5. identifying the causes relating the variance (objectives-results);

6. identifying the improvements to adopt in order to reach new future training programs.

\subsection{Identifying the Stakeholders Involved and the Objects of the Evaluation}

At the outset, the specific stakeholders who will be involved must be defined (Mark - Shotland, 1985; Greene, 1988; Reineke, 1991) and the object (or objects if there are more than one) which will be under evaluation must be decided upon. Then, stakeholders in the evaluation process must be immediately engaged following identification, as many critical decisions affecting evaluation occur early on in the process, and their involvement ensures higher fairness in the evaluation process. This is particularly relevant in the phases of defining the criteria, identifying the KPIs and collecting and analyzing data.

The Table 1 shows the main stakeholders involved in a training project so called, for instance, " $\mathrm{X}$ ":

Table 1. Own elaboration Project " $X$ "

\begin{tabular}{ll}
\hline Kind of Stakeholders & Role \\
\hline Target Participants & Stakeholders directly involved in the training program \\
\hline Decision Makers & $\begin{array}{l}\text { Individuals who activate the training project (and } \\
\text { probably finance or ask to be financed by the } \\
\text { Organization). They must monitor this implementation. }\end{array}$ \\
\hline Program Staff & $\begin{array}{l}\text { Individuals who carry out and support the planned } \\
\text { activities by the training project }\end{array}$ \\
\hline Program Managers & $\begin{array}{l}\text { Individuals involved in the oversight and the managing of } \\
\text { the training project }\end{array}$ \\
\hline Contextual Stakeholders & $\begin{array}{l}\text { Individuals not directly involved in the training project } \\
\text { but they are able to influence the final results }\end{array}$ \\
\hline
\end{tabular}

Subsequently, the objects of the evaluation are identified. Following are some possible objects of evaluation:

$>$ level of learning;

$>$ satisfaction of direct and indirect users;

$>$ work skills acquired;

$>$ efficiency of working methods;

$>\quad$ validity of training tools;

$>$ effectiveness of the professional trainer; 
suitability of the training methods adopted;

$>$ comparison between results of productivity (in term of core business of the organization) before and after the training program development.

\subsection{Determining the Criteria for Quality Assessing (KPIs)}

In order to draft a final report focused on the quality of the training project, a series of evaluation criteria must be identified to establish the single "area" submitted to further evaluation. These criteria are briefly shown in Table 2.

Table 2. The evaluation criteria

\begin{tabular}{ll}
\hline Evaluation Criteria & Question to be asked \\
\hline Relevance & $\begin{array}{l}\text { Is the training project to be implemented? Does it concern the needed requirements } \\
\text { for the Organization? What must be done to meet these needs and standards? }\end{array}$ \\
\hline Adequacy & To what extent are employee needs and standards met? \\
\hline Innovation & What new skills could be used to produce the desired changes? \\
\hline Efficacy & $\begin{array}{l}\text { Is the training program having the desired effects? What is the level of coherence } \\
\text { with the employees emerged needs? }\end{array}$ \\
\hline Efficiency & $\begin{array}{l}\text { Has the formed intervention implemented and satisfied positive relationships } \\
\text { between expected objectives, available resources, and possible constraints? }\end{array}$ \\
\hline $\begin{array}{l}\text { Cost-benefit } \\
\text { analysis }\end{array}$ & $\begin{array}{l}\text { Are program effects attained at a reasonable cost? What is the alternative to } \\
\text { financing the training project beyond the internal funds? }\end{array}$ \\
\hline Results & $\begin{array}{l}\text { Is the training program operating as planned? Do the results reflect what was } \\
\text { initially planned? }\end{array}$ \\
\hline Sustainability & $\begin{array}{l}\text { Is the training program effectively sustainable with the other job commitments of } \\
\text { the involved employees? Is it a potential cause of stress and absenteeism? }\end{array}$ \\
\hline $\begin{array}{l}\text { Multiplying } \\
\text { effect }\end{array}$ & $\begin{array}{l}\text { Did the training program generate positive circuits? For instance, is it reproducible, } \\
\text { transferable, with the possibility to repeat the same training program in similar } \\
\text { contexts? }\end{array}$ \\
\hline $\begin{array}{l}\text { Image \& } \\
\text { Reputation }\end{array}$ & $\begin{array}{l}\text { How should the effect be put in terms of image (internal and external)? Which of the } \\
\text { possible alternative programs is best to create better results in terms of reputation? }\end{array}$ \\
\hline
\end{tabular}

Then, the single "area" is shown in the Table 3. This is the basis to proceed to identification of key performance indicators (KPIs). This is simply an example of the complete framework and it is identifying n. 5 AREA submitted to evaluation judgment from A to D:
A. Excellent
B. Good
C. Sufficient, Just adequate
D. Poor, inadequate. 
Table 3. The KPIs identified to evaluate the single "area"

\begin{tabular}{|c|c|c|}
\hline AREA & KPI/Evaluation, Opinion & Evaluation, Opinion (To A since D) \\
\hline \multirow[t]{4}{*}{ 1. Time Management AREA } & KeyTMA & \\
\hline & The duration of course was too short & \\
\hline & The duration of course was too long & \\
\hline & $\begin{array}{l}\text { The duration of the course was really } \\
\text { optimal compared with what I needed } \\
\text { to know }\end{array}$ & \\
\hline \multirow[t]{3}{*}{ 2. Hours Management AREA } & КеуНМА & \\
\hline & $\begin{array}{l}\text { The course schedules have been } \\
\text { studied in a very good way }\end{array}$ & \\
\hline & $\begin{array}{l}\text { The course schedules were difficut in } \\
\text { terms of attention and comittment }\end{array}$ & \\
\hline \multirow[t]{3}{*}{ 3. Teaching AREA } & KeyTA & Evaluation, Opinion (To A since D) \\
\hline & $\begin{array}{l}\text { The professional trainer (or trainers if } \\
\text { there are more than one) was really } \\
\text { prepared }\end{array}$ & \\
\hline & $\begin{array}{l}\text { The professional trainer (or trainers if } \\
\text { they are more than one) was not } \\
\text { adequate }\end{array}$ & \\
\hline \multirow[t]{4}{*}{ 4. Content AREA } & КеуCA & Evaluation, Opinion (To A since D) \\
\hline & $\begin{array}{l}\text { The content of the course was too } \\
\text { technical }\end{array}$ & \\
\hline & $\begin{array}{l}\text { The content of the course was too } \\
\text { "light" }\end{array}$ & \\
\hline & $\begin{array}{l}\text { The content of the course was } \\
\text { completely inadequate for our sector }\end{array}$ & \\
\hline \multirow[t]{3}{*}{ 5. Organizational AREA } & КeyOA & Evaluation, Opinion (To A since D) \\
\hline & $\begin{array}{l}\text { The course was held in an appropriate } \\
\text { classroom }\end{array}$ & \\
\hline & $\begin{array}{l}\text { The course was held in an inadequate } \\
\text { classroom (light, acoustics...) }\end{array}$ & \\
\hline \multirow[t]{3}{*}{ 6. Reputational AREA } & KeyRA & Evaluation, Opinion (To A since D) \\
\hline & $\begin{array}{l}\text { The course was optimal to improve } \\
\text { the image of PA (thanks to high } \\
\text { knowledge of employee and the } \\
\text { capability to offer a best quality } \\
\text { services) }\end{array}$ & \\
\hline & $\begin{array}{l}\text { The course was excellent to enhancing } \\
\text { the Reputation of PA trough their own } \\
\text { employees (thanks to more skills of } \\
\text { employee, to obtain best performance) }\end{array}$ & \\
\hline
\end{tabular}

With reference to the standard-values referring to KPIs, it is first necessary to know if there are limits imposed by the actual regulations (for instance in terms of the amount of training hours to be carried out), secondly, if they do not 
exist, a series of threshold-values must be prepared and then compared to the results of the relevant KPIs. The Table 4 shows an example of this formulation.

Table 4. The KPIs identified to evaluate the single "area"

\begin{tabular}{ll}
\hline AREA & KPIs Standard Value \\
\hline Time Management AREA & No more $10 \%$ for $\mathrm{D}$ \\
KeyTMA & At least around $40 \%$ for A \\
& At least around $30 \%$ for B \\
& No more than $20 \%$ of C \\
\hline Teaching AREA & No more than $5 \%$ for D \\
KeyTA & At least around $30 \%$ for A \\
& At least around $40 \%$ for B \\
& No more than $15 \%$ of C \\
\hline
\end{tabular}

\subsection{Collection, Selection and Organization of Data}

Generally, a questionnaire is the most widely used tool in these evaluation cases. In recent years it has become increasingly common for the questionnaire to appear in digital versions, in replacement of the old paper version, supporting the environmental responsibility to avoid the pollution and wasteful attitudes. The Table 5 shows an example of results.

Table 5. Results deriving from questionnaire

\begin{tabular}{lllll}
\hline Time Management AREA & Data Results & & & \\
\hline KeyTMA & $\mathrm{A}(\%)$ & $\mathrm{B}(\%)$ & $\mathrm{C}(\%)$ & $\mathrm{D}(\%)$ \\
\hline KeyHMA & $55(61 \%)$ & $12(13 \%)$ & $18(20 \%)$ & $5(6 \%)$ \\
\hline Teaching AREA & $11(12 \%)$ & $63(70 \%)$ & $4(5 \%)$ & $12(13 \%)$ \\
\hline KeyTA & $\ldots$ & $\ldots$ & $\ldots$ \\
\hline Content AREA & $\ldots$ & $\ldots$ & $\ldots$ \\
\hline KeyCA & $\ldots$ & $\ldots$ & $\ldots$ \\
\hline Organizational Area & $\ldots$ & $\ldots$ & $\ldots$ \\
\hline KeyOA & $\ldots$ & $\ldots$ & $\ldots$ \\
\hline Reputational Area & $\ldots$ & $\ldots$ & $\ldots$ \\
\hline KeyRA & $\ldots$ & $\ldots$ & $\ldots$ \\
\hline
\end{tabular}

\subsection{Comparison Between the Performances Obtained and the Planned Objective}

This is the first important phase of evaluation utilizing the first result. With the comparison of results from tables 3 , 4 and 5. To analyze the proposed example, the results for KeyTMA is useful because it is adequate with the threshold-values established in tab. 4. But the results of KeyHMA express values which are not adequate with the threshold-values established in the tab. 4: specifically the value of A below-level, the value of B and C are expected, and finally the value of $\mathrm{D}$ is high, so it is necessary to intervene to alter these results. 


\subsection{Identifying the Causes Relating the Variance (Objectives-Results)}

A consequence of the previous step, which allowed to highlight which variances are generated with the comparison with objectives planned and results. The analysis in this step refers to identifying the causes of these variance and to go towards the determination of possible solutions to adopt in further steps.

\subsection{Identifying the Improvements to Adopt in Order to Reach New Future Training Programs}

In this step, decisions should be made about what changes will be provided and appropriate ways to do this.

This step is important to both the determination of the activities to adopt for the future improvement of the training program and the conclusion of the evaluation process.

A final evaluation of the entire process should be made in this moment. In order to improve both the future training programs and the training evaluation models, is important to define the positive and negative elements referred to in this process. Step by step it will be possible to personalize these models with reference to characteristics of PA involved.

\section{Conclusion}

In this article, a focus was placed on the evaluation of training projects, specifically in the sector of PA. A participatory philosophy is adopted, by the involvement of individuals who actively participate in the training project (stakeholder-based evaluation), since it is believed that they provide more information for evaluation. A final report was reached, but in this study, it is considered just the first step. The most important element realized was the necessity of protecting resources that may potentially be invested, especially in the public context, to avoid a waste of resources (in this case, public resources) that could be generated as a result of bad investments.

The training audit is therefore essential on this end: thanks to a deeper evaluation, carried out at different times (ex-ante, ongoing, ex-post), a series of information can be obtained that allows decision making to act promptly.

\subsection{Limitation of the Study}

The main limit of the research is that this study is still at an early stage of building of the proposed model.

This study, like every initial study, presents numerous limitations given by the first step of the research.

The limits are also contained in the identification of the criteria of used methods, since being one of the first processes started in the determination of the final evaluation in a training, it is understood that it must undergo successive revisions and modifications.

\subsection{Future Research}

The models and work schemes proposed in the present study follow a logical path marked by the different moments of analysis and activity.

The aim is to propose an idea about the method to be acquired and to be personalized for each organization, based on different characteristics of each public structure. A necessary assessment activity is requested. The approach used is inductive.

The starting point is a rigid scheme, which is based on the assumptions of classical studies, based on the analysis of needs up to the evaluation of the results but, within the same scheme it was introduced a series of different subjective elements towards a "personalization" of the evaluation process.

They depend on the characteristics of the organization, the knowledge needs, which stakeholders have been involved, and finally, which performance indicators must be identified. KPIs are both subjective and objective, and therefore permit assessments and qualitative and quantitative results.

Future steps of research in this field will be mainly focused on empirical research, through case studies on which to test the experience of customization of the audit process and permit the evaluation methods contained in this paper. Furthermore, the assessment of training HR on intangibles aspects must be optimized, such as further emphasis on the increasingly important Reputation of the PA.

\section{References}

Barney, J. B. (1991). Firm resources and sustained competitive advantage. Journal of Management, 17, 99-120. https://doi.org/10.1177/014920639101700108

Bates, R. A. (2004). A critical analysis of evaluation practice: the Kirkpatrick model and the principle of beneficence. Evaluation and Program Planning, 27, 341-7. https://doi.org/10.1016/j.evalprogplan.2004.04.011 
Borgonovi, E. (2004). Principi e sistemi aziendali per le amministrazioni pubbliche, Egea, Milano, $4^{\wedge}$ edizione.

Cabello-Medina, C., Lopez-Cabrales, A., \& Valle-Cabrera, R. (2011), Leveraging the innovative performance of human capital through HRM and social capital in Spanish firms. International Journal of Human Resource Management, 22(4), 807-828. https://doi.org/10.1080/09585192.2011.555125

Collins, C. J., \& Clark, K. D. (2003). Strategic human resource practices, top management team social networks, and firm performance: The role of human resource practices in creating organizational competitive advantage. Academy of Management Journal, 46, 740-751. https://doi.org/10.2307/30040665

Collis, D. J. (1994). Research note: how valuable are organizational capabilities?. Strategic Management Journal, 15, 143-152. https://doi.org/10.1002/smj.4250150910

De Winne, S., \& Sels, L. (2010). Interrelationships between human capital, HRM and innovation in Belgian start-ups aiming at an innovation strategy. International Journal of Human Resource Management, 21, 1860-1880. https://doi.org/10.1080/09585192.2010.505088

Eisenberger, R., Huntington, R., Hutchison, S., \& Sowa, D. (1986). Perceived organizational support. Journal of Applied Psychology, 71, 500-507. https://doi.org/10.1037/0021-9010.71.3.500

Gong, Y., Law, K. S., Chang, S., \& Xin, K. R. (2009). Human resource management and firm performance in China: The different role of managerial affective and continuance commitment. Journal of Applied Psychology, 94, 263-275. https://doi.org/10.1037/a0013116

Greene, J. G. (1988). Stakeholder Participation and Utilization in Program Evaluation. Evaluation Review, 12(21), 91-116. https://doi.org/10.1177/0193841X8801200201

Guthrie, J. P. (2001). High-involvement work practices, turnover, and productivity: evidence from New Zealand. Academy of Management Journal, 44(1), 180-190. https://doi.org/10.2307/3069345

Hinna, A., Mangia, G., \& De Nito, E. (2010). Board of director within public organizations: A literature review. International Journal of Business Governance and Ethics, 5(3), 131-156. https://doi.org/10.1504/IJBGE.2010.033343

Hood, C., James, O., \& Scott, C. (2000). Regulation of government: Has it increased, is it increasing, should it be diminished?. Public Administration, 78(2), 283-304. https://doi.org/10.1111/1467-9299.00206

Huselid, M. A. (1995). The impact of human resource management practices on turnover, productivity, and corporate financial performance. Academy of Management Journal, 38(3), 635-672. https://doi.org/10.2307/256741

Jiang, J. Y., \& Liu, C-W. (2015). High performance work systems and organizational effectiveness: The mediating role of social capital. Human Resource Management Review, 25(1), 126-137. https://doi.org/10.1016/j.hrmr.2014.09.001

Jørgensen, T. B. (1999). The Public Sector in an in-between time: Searching for new public values. Public Administration, 77(3), 565-584.

Juárez Tarrega, A., Marin-Garcia, J., \& Santandreu-Mascarell, C. (2019). What are the main concerns of human resource managers in organizations?. Intangible Capital, 15(1), 72-95. https://doi.org/10.3926/ic.1342

Kearsley, G. (1982). Costs, benefits and productivity in training systems. Reading, MA, Addison Wesley.

Kearsley, G., \& Compton, T. (1981). Assessing cost, benefits and productivity in training systems. Training and Development Journal, 1.

Kianto, A., Sáenz, J., \& Aramburu, N. (2017). Knowledge-based human resource management practices, intellectual capital and innovation. Journal of Business Research, 81, 11-20. https://doi.org/10.1016/j.jbusres.2017.07.018

Kirkpatrick, D. L. (1959a). Techniques for evaluating training programs. Journal of ASTD, 13(11), 3-9.

Kirkpatrick, D. L. (1959b). Techniques for evaluating training programs: Part 2--Learning. Journal of ASTD, 13(12), 21-26.

Kirkpatrick, D. L. (1960a). Techniques for evaluating training. Journal of ASTD, 14(1), 13-18.

Kirkpatrick, D. L. (1960b). Techniques for evaluating training programs: Part 4--Results. Journal of ASTD, 14(2), 28-32.

Kirkpatrick, D. L. (1976). Evaluation of training. In R. L. Craig (Ed.), Training and development handbook: A guide to human resourcedevelopment. New York: McGraw Hill. 
Kirkpatrick, D. L. (1994). Evaluating training programs: the four levels. San Francisco: Berrett-Koehler.

Kirkpatrick, D. L., \& Kirkpatrick, J. D. (2005). Transferring learning to behavior. Using the four levels to improve performance. San Francisco, CA: Berrett-Koehler.

Klijn, E., \& Skelcher, C. (2007). Democracy and governance networks: Compatible or not?. Public Administration, 85(3), 587-608. https://doi.org/10.1111/j.1467-9299.2007.00662.x

Knott, J., \& Miller, G. (2006). Social Welfare, Corruption and Credibility. Public Management Review, 8(2), $227-52$. https://doi.org/10.1080/14719030600587455

Lin, X., \& Tang, H. (2016), A framework for Human Resource Configurations in Knowledge-intensive Organizations. International Journal of Business Administration, 7(1). https://doi.org/10.5430/ijba.v7n1p1

Lowndes, V., \& Wilson, D. (2003). Balancing revisability and robustness? A new institutionalist perspective on modernization. Public Administration, 81(2), 275-298. https://doi.org/10.1111/1467-9299.00346

Magone, J. M. (2011). The Difficult Transformation of the State and Public Administration in Portugal. Public Administration, 89, 756-782. https://doi.org/10.1111/j.1467-9299.2011.01913.x

Mark, M. M., \& Shotland, R. L. (1985). Stakeholder-Based Evaluation and Value Judgments: The Role of Perceived Power and Legitimacy in the Selection of Stakeholder Groups. Evaluation Review, 9, 605-626. https://doi.org/10.1177/0193841X8500900504

Marshall, A. (1890). Principles of Economics: an introductory volume. London, Macmillan.

Mayer, R. C., Davis, J. H., \& Schoorman, F. D. (1995). An integrative model of organizational trust. Academy of Management Review, 20(3), 709-734. https://doi.org/10.5465/amr.1995.9508080335

Meek, J. W. (2010). Complexity theory for public administration and policy. Emergence: Complexity \& Organization, 12(1), 1-4.

Meier, K. J., \& O' Toole, L. G. (2011). Comparing public and private management: Theoretical expectations. Journal of Public Administration Research and Theory, 21, 1283-1299. https://doi.org/10.1093/jopart/mur027

Meneguzzo, M. (2005), Creazione di valore e sviluppo del capitale sociale: la sfida per il sistema della PA italiana. RIREA, 11(12), 705-720.

Meyer, R. E., Egger-Peitler, I., Höllerer, M. A., \& Hammerschmid, G. (2014). Of Bureaucrats and Passionate Public Managers: Institutional Logics, Executive Identities and Public Service Motivation. Public Administration, 92(4), 861-885. https://doi.org/10.1111/j.1467-9299.2012.02105.x

Miao, Q. N., Schwarz, A., \& Cooper, G. B. (2017), How Leadership and Public Service Motivation Enhance Innovative Behavior. Public Administration Review, 78(1), 71-81. https://doi.org/10.1111/puar.12839

Noordegraaf, M., \& Abma, T. (2003). Management by measurement? Public management practices amidst ambiguity. Public Administration, 81, 853-871. https://doi.org/10.1111/j.0033-3298.2003.00374.x

Ordóñez de Pablos, P. (2004), Measuring and reporting structural capital: lessons from European learning firms. Journal of Intellectual Capital, 5(4), 629-47. https://doi.org/10.1108/14691930410567059

Patton, M. Q. (1998). Discovering Process Use. Evaluation, 4(2), $225-233$. https://doi.org/10.1177/13563899822208437

Penrose, E. T. (1959). The Theory of Growth of the Firm. London, Basil Blackwell.

Phillips, J. J. (1991). Handbook of training evaluation and measurement methods (2nd ed.). Houston, Gulf.

Phillips, J. J. (1996), ROI: the search for best practices, Training \& Development, 50, 42-47.

Phillips, J. J. (1997). Return on Investment in Training and Performance Improvement Programs. Houston, Gulf Publishing Company.

Phillips, P. P., \& Phillips, J. J. (2001). Symposium on the evaluation of training: editorial. International Journal of Training and Development, 5, 240-247. https://doi.org/10.1111/1468-2419.00136

Pollit, C., \& Bouckaert, G. (2000). The nature of public management reform, Public Management Reform: A Comparative Analysis. Oxford University Press, New York, NY, pp. 6-23.

Porter, M. E. (1985). Competitive advantage. New York: The Free Press. 
Power, M. (2000). The audit society-Second thoughts. International Journal of Auditing, 4, 111-119. https://doi.org/10.1111/1099-1123.00306

Reineke, R. A. (1991). Stakeholder involvement in evaluation: Suggestions for practice. American Journal of Evaluation, 12, 39-44. https://doi.org/10.1177/109821409101200106

Rhoades, L., \& Eisenberger, R. (2002). Perceived organizational support: A review of the literature. Journal of Applied Psychology, 87, 698-714. https://doi.org/10.1037/0021-9010.87.4.698

Rodwell, J. J., \& Teo, S. T. (2008). The influence of strategic HRM and sector on perceived performance in health service organizations. International Journal of Human Resource Management, 19(10), 1825-1841. https://doi.org/10.1080/09585190802323934

Rothstein, H., \& Downer, J. (2012). Renewing DEFRA: Exploring the Emergence of Risk-Based Policymaking in UK Central Government. Public Administration, 90(3). https://doi.org/10.1111/j.1467-9299.2011.01999.x

Sanderson, I. (2002). Performance management, evaluation and learning in 'Modern' Local Government. Public Administration, 79(2), 297-313. https://doi.org/10.1111/1467-9299.00257

Smith, M., \& Beazley, M. (2000). Progressive regimes, partnerships and the involvement of local communities: a framework for evaluation. Public Administration, 78(4), 855-878. https://doi.org/10.1111/1467-9299.00234

Sullivan, H., Barnes, M., \& Matka, E. (2006). Collaborative Capacity and strategies in area-based initiatives. Public Administration, 84(2), 289-310. https://doi.org/10.1111/j.1467-9299.2006.00003.x

Sun, L., Aryee, S., \& Law, K. S. (2007). High-performance human resource practices, citizenship behavior, and organizational performance: A relational perspective. Academy of Management Journal, 5, 558-577. https://doi.org/10.5465/amj.2007.25525821

Talbot, C. (2010). Theories of Performance. Organizational and Service Improvement in the Public Domain. Oxford, Oxford University Press.

Teece, D. J., Pisano, G., \& Shuen, A. (1997). Dynamic capabilities and strategic management. Strategic $\begin{array}{lll}\text { Management } & \text { Journal, } & \text { 509-533. }\end{array}$ https://doi.org/10.1002/(SICI)1097-0266(199708)18:7<509::AID-SMJ882>3.0.CO;2-Z

Tomo, A. (2018). Advancing a Behavioral Approach for Studying Public Administration. International Journal of Business and Management, 13(6), 25-42. https://doi.org/10.5539/ijbm.v13n6p25

Wernerfelt, B. (1984). A resource-based view of the firm. Strategic Management Journal, 5, 171-180. https://doi.org/10.1002/smj.4250050207

Youndt, M. A., \& Snell, S. A. (2001). Human resource management, intellectual capital and organizational performance. Working Paper, Skidmore College. 